Asia Proceedings of Social Sciences

(APSS)

www.readersinsight.net/APSS

\title{
Determinants of Green Product Purchase Intention
}

\section{Thoo Ai Chin*}

Department of Business Administration (Marketing), Azman Hashim International Business School, Universiti Teknologi Malaysia

Malaysia

\section{Nor Haslinda binti Mohd Lawi}

Department of Business Administration (Marketing), Azman Hashim International Business School, Universiti Teknologi Malaysia

Malaysia

\section{Farrah Merlinda Muharam}

Department of Business Administration (Entrepreneurship), Azman Hashim International Business School,

Universiti Teknologi Malaysia

Malaysia

\section{Umar Haiyat Abdul Kohar}

Department of Business Administration (Entrepreneurship), Azman Hashim International Business School, Universiti Teknologi Malaysia

Malaysia

\section{Tan Liat Choon}

Department of Geinformation, Faculty of Built Environment and Surveying, Universiti Teknologi Malaysia Malaysia

\section{Norhayati Zakuan}

Department of Business Administration (Quantitative), Azman Hashim International Business School,

Universiti Teknologi Malaysia

Malaysia

*Corrosponding author's Email: acthoo@utm.my

Peer-review under responsibility of $4^{\text {th }}$ Asia International Conference 2018 editorial board

(http://www.utm.my/asia/our-team/)

(C) 2018 Published by Readers Insight Publisher,

lat 306 Savoy Residencia, Block 3 F11/1,44000 Islamabad. Pakistan,

info@readersinsight.net

This is an open access article under the CC BY-NC-ND license (http://creativecommons.org/licenses/by-nc-nd/4.0/). 


\section{Research High Iight s}

There are three hypotheses were developed for the study. The first hypothesis is about the relationship between green brand positioning and green product purchase intention. The second hypothesis is about the relationship between green brand knowledge and green product purchase intention. The third hypothesis is about the relationship between attitude towards green brand and green product purchase intention. Out of the three hypotheses, only two hypotheses are supported which are green brand positioning and green brand knowledge on green product purchase intention. The green consumer knowledge has biggest impact on green product purchase, followed by green brand positioning. The attitude towards green brand has no relationship with green product purchase intention. The study found that the adjusted $\mathrm{R}^{2}$ is 0.776 . This means approximately $77.6 \%$ of the green products purchase intention could be explained by the green brand positioning and green brand knowledge.

\section{Research Objectives}

This study aims to investigate the determinants of green product purchase intention. The determinants include green brand positioning, green brand knowledge and attitude towards green brand. Nowadays, customers are starting to buy green products as they are aware about the environmental conservation. In fact, Malaysia strives to reduce environmental risks through numerous green initiatives. On the other hand, literatures about green marketing including green buying behaviour and green branding are increasing in developed countries and developing countries such as Malaysia (Yadav and Pathak, 2016). It is important to increase the awareness of green product among consumers in Malaysia, therefore future studies about that are required. In fact, many consumers have limited knowledge about green products and their quality (Suki, 2016). As such, it is an urgent need to educate consumers and increase their awareness about going green for sustainability. Similarly, companies should provide important green product information to consumers and increase their green brand knowledge about the green products in order to increase the sales of the green products (Suki, 2016). In addition, the company should focus on price, quality and advertisement in order to enhance the demand of the green purchase. 


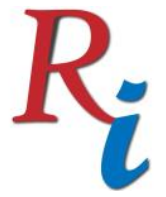

Asia Proceedings of Social Sciences

(APSS)

www.readersinsight.net/APSS

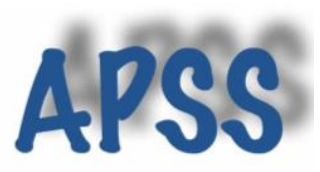

\section{Methodology}

The population of the study included the consumers who have intention to purchase green products. Nonprobability sampling technique such as snowball sampling technique was used for data collection. A sample size of 150 is sufficient to conduct a research (Malhotra, 2012). As such, 162 respondents were invited to answer the questionnaire with less than 10 minutes for the survey. Quantitative research method using questionnaire was employed in the study. Google form was used to distribute the questionnaire to the respondents. A five-point Likert scale was used to determine the consumer's level of agreement about the questionnaire statements: 'strongly disagree', 'disagree', 'neutral', 'agree', and 'strongly agree'. The questionnaire is widely recommended as the most important tool for a research and data collection. The questionnaire was developed into two parts: Section A is about respondent background and Section B includes questions about green brand positioning, green brand knowledge, attitude towards green brand and green products purchase intention. Multiple regression was used to examine the relationships between green brand positioning, green brand knowledge, attitude towards green brand and green product purchase intention.

\section{Results}

A total of 162 respondents with 82 female (50.6\%) and 80 male (49.4\%) participated in the study. Majority of the respondents aged 25 and below (37.0\%), followed by 25 to 35 (21.0\%) and 36 to 45 years old (17.3\%). Most of the respondents had a bachelor degree and 22.8\% had diploma or STPM. Majority of the respondents earned RM1,000 and below (23.5\%) followed by RM3,001 to RM4,000 (22.8\%), RM2,001 to RM3,000 (19.1\%), RM4,001 to RM5,000 (14.8\%), RM5,000 and above (13.0\%) and RM1,001 to RM2,000 (6.8\%). Many of the respondents had experience to purchase green products $1-5$ times for the past 3 months $(37.0 \%)$ and most of them were influenced by family member $(29.1 \%)$, friends $(28.4 \%)$, social media $(25.3 \%)$ and neighbours $(8.6 \%)$ for the green product purchase. For reliability test, the values of Cronbach Alpha for green brand positioning, green brand knowledge, attitude towards green brand and green products purchase intention are higher than 0.7 , which indicates that all of the variables are reliable. Multiple regression analysis was used to test the research hypotheses. The results found that green brand positioning and green brand knowledge are positively and significantly related to green products purchase intention. 


\section{Findings}

This study found that green brand positioning and green brand knowledge have a positive and significant relationship with green product purchase intention. Brand knowledge has the highest impact on green product purchase intention. The findings of the study are essential to green companies and marketers. Companies should help to increase consumers' green awareness through media influences and campaigns. In support, green marketers could ensure the accessibility of the green products in order to increase the demand of green products since many consumers are likely to purchase green product due to the positive environmental impact.

\section{References}

Malhotra, N. K. (2012). Basic Marketing Research. 4th ed., Pearson, USA.

Suki, N. M. (2016). Green product purchase intention: impact of green brands, attitude, and knowledge. British Food Journal, 118(12), 2893-2910.

Yadav, R., and Pathak, G. S. (2016). Young consumers' intention towards buying green products in a developing nation: Extending the theory of planned behavior. Journal of Cleaner Production, 135, 732-739. 